\title{
Prediksi Harga Beras Sultan dan Membramo di Kota Manado dengan Menggunakan Model ARIMA
}

\section{Varra Wuwunga*, Nelson Nainggolana, Marline Paendonga}

aJurusan Matematika, FMIPA, Unsrat, Manado

\section{KATA KUNCI}

Model ARIMA

Harga Beras

Time series

\section{KE YW O R D S}

ARIMA Models

The Rice Price

Time series

\begin{abstract}
A B S T R A K
Pada makalah ini diuraikan model ARIMA dari harga beras di kota Manado yang meliputi beras Sultan dan beras Membramo. Data yang diamati adalah data bulanan dari Januari 2007 sampai dengan Maret 2012. Hasil analisis time series menunjukan bahwa untuk beras Sultan diperoleh model $\operatorname{ARIMA}(1,1,1)$ dan beras Membramo diperoleh model $\operatorname{ARIMA}(1,1,0)$. Hasil diagnosis menunjukan bahwa galat dari model untuk beras Sultan dan beras Membramo sudah berdistribusi normal dengan $p$ value lebih dari 0,05 yaitu masing-masing 0,15 dan 0,07. Prediksi harga beras untuk tiga periode kedepan untuk beras Sultan berkisar antara Rp. 8.287 sampai Rp. 8.389, dan beras Membramo berkisar antara Rp. 8.482 sampai Rp. 8.593.

A B S T R A C T

This paper described ARIMA models of the rice prince in Manado, that is sultan and membramo rice. The observed data is monthly from January2007 to March-2012. The result show that the models for sultan is $\operatorname{ARIMA}(1,1,1)$ and for membramo is $\operatorname{ARIMA}(1,1,0)$. The diagnosis results show that the residuals of the models for sultan and membramo is normally distributed with a $p$-value more than 0,05 , that is 0,15 and 0,07 respectively. The prediction of price for the next three periods for sultan from Rp. 8.287,30 to Rp. 8.389,92 and for membramo from Rp. 8.482 to Rp. 8.593.
\end{abstract}

\section{AVAILABLE ONLINE}

29 Januari 2013
Model Autoregresive (AR) adalah model yang menyatakan bahwa nilai pengamatan pada waktu sebelumnya ditambah galat. Dengan kata lain nilai $Z_{t}$ pada waktu t diregresikan pada nilai-nilai sebelumnya dari dirinya sendiri ditambah white noise.

Model Moving Average (MA) adalah model yang nilai $Z_{t}$ bergantung pada suku-suku white noise waktu sekarang dan waktu-waktu sebelumnya.

Model ARMA (Autoregresive Moving Average) adalah gabungan dari model AR dan MA. Model ARMA merupakan model untuk data yang stasioner, namun data yang dianalisis tidak selamanya menunjukkan kestasioneran, sebab data yang tidak stasioner seringkali didapati dikehidupan nyata. Salah satu cara menstasionerkan data adalah melalui proses pembedaan (differencing). harga tahun. Hal ini dapat dilihat pada Januari 2007 harga rata-rata beras per kilogram Rp.5.200, Januari 2008 Rp.5.700 dan Januari 2012 Rp.8.600. Data ini menunjukkan bahwa harga beras tidak stasioner. 
Model ARIMA adalah model time series yang dapat diaplikasikan untuk data yang tidak stasioner. Secara umum persamaan model ARIMA adalah [1] :

$$
\begin{gathered}
Z_{t}-Z_{t-1}=\phi_{1}\left(Z_{t-1}-Z_{t-2}\right)+\phi_{2}\left(Z_{t-2}-Z_{t-3}\right)+\ldots \\
+\phi_{p}\left(Z_{t-p}-Z_{t-p-1}\right)+\varepsilon_{t}-\theta_{1} \varepsilon_{t-1} \\
-\ldots-\theta_{q} \varepsilon_{t-q}
\end{gathered}
$$

dimana $\varepsilon_{t_{\sim}}^{i i d} N\left(0, \sigma^{2}\right)$.

\section{Metode}

Data yang digunakan adalah data sekunder. Data berupa data kuantitatif harga bulanan beras dengan data harga beras sebanyak 63 data yaitu data periode bulan Januari 2007 sampai dengan bulan Maret 2012 yang diperoleh dari Divisi Regional (Divre) Bulog Provinsi Sulawesi Utara. Digunakan dua jenis beras dalam mencari prediksi harga beras di kota Manado yaitu beras Sultan, dan beras Membramo. Hal ini karena beras tersebut merupakan beras yang dapat diperoleh berbagai kalangan. Tahapan analisis data mengikuti 3 tahap dari Box-Jenkins yaitu:
1) Identifikasi model
2) Penentuan Parameter model
3) Diagnostik model

\section{Hasil dan Pembahasan}

3.1. Harga Bulanan Beras Sultan dan Beras Membramo Periode Jan-2007 sampai dengan Mar2012

Eksplorasi data harga bulanan beras Sultan dan Membramo periode bulan Januari 2007 sampai dengan bulan Maret 2012 sebanyak 63 data yang dapat dilihat pada Gambar 1.

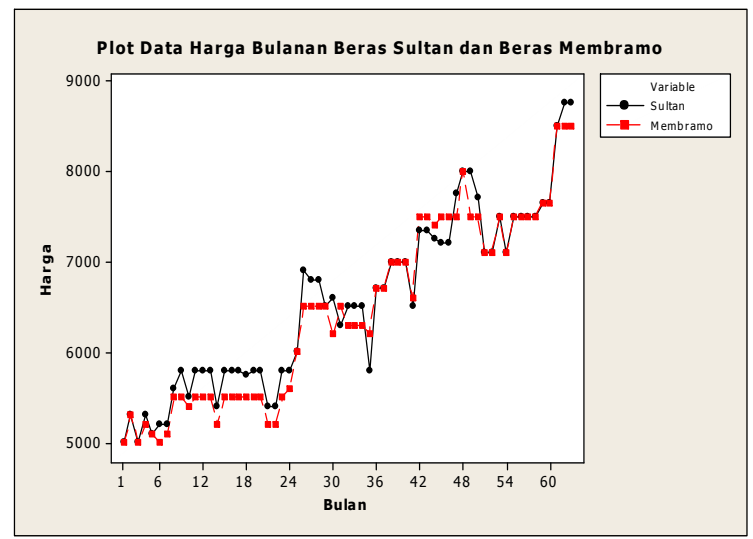

Gambar 1 - Plot Data Harga Bulanan Beras Sultan dan Membramo

Pada Gambar 1 terlihat bahwa untuk harga beras Sultan (garis hitam), harga beras diawali dengan Rp.5.000 dibulan Januari 2007 dan mengalami kenaikan harga menjadi Rp.6.700 diawal tahun 2010, harga beras terus meningkat sampai Rp.7.650 diakhir tahun 2011 hingga bulan Maret 2012 harga beras menjadi Rp. 8.750 .
Untuk beras Membramo (garis merah), harga beras diawali dengan Rp.5.000 dibulan Januari 2007 dan mengalami kenaikan harga menjadi Rp.6.700 diawal tahun 2010, harga beras terus meningkat sampai Rp.7.650 diakhir tahun 2011 hingga bulan Maret 2012 harga beras menjadi Rp. 8.500.

Analisis selanjutnya adalah melakukan plot ACF dan PACF. Dari Gambar 1 diketahui bahwa data yang diperoleh tidak stasioner dalam rata-rata maka dilakukan proses pembedaan tingkat pertama (selisih orde-1) seperti pada Gambar 2.

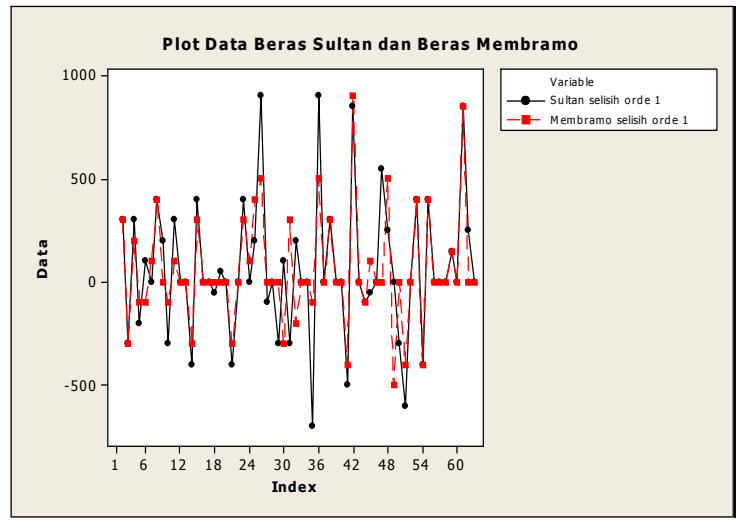

Gambar 2 - Plot Data Harga Bulanan Beras Sultan Pembedaan Orde-1 dan Beras Membramo Pembedaan Orde-1

Gambar 2 menunjukkan bahwa untuk beras Sultan dan beras Membramo setelah dilakukan proses selisih plot data sudah bersifat stasioner artinya nilai $d$ yang dapat digunakan adalah $d=1$.

4.2. Menentukan Persamaan Model ARIMA ( $p, d, q)$ Data Harga Bulanan Beras Sultan dan Beras Membramo Periode Bulan Januari 2007 sampai dengan Bulan Maret 2012

Dari hasil penentuan identifikasi model diperoleh bahwa model yang cocok untuk beras Sultan adalah ARIMA(1,1,1) dengan koefisien parameter yaitu: $A R(1)$ $=0,5495$ dan $\mathrm{MA}(1)=0,9665$. Persamaan $\operatorname{ARIMA}(1$, 1, 1) untuk beras sultan menjadi:

$$
\begin{aligned}
& Z_{t}-Z_{t-1}=\phi_{1}\left(Z_{t-1}-Z_{t-2}\right)+\varepsilon_{t}-\theta_{1} \varepsilon_{t-1} \\
& Z_{t}=(1+0,5495) Z_{t-1}-(0,5495) Z_{t-2}+\varepsilon_{t} \\
& -0,9665 \varepsilon_{t-1} \\
& Z_{-}{ }^{\prime}=1,5495 \nabla Z \rrbracket_{-}(t-1) \quad \|-0,5495 Z \nabla_{-}(t \\
& -2)-\quad 0,9665 \varepsilon_{-}(t-1)
\end{aligned}
$$

Untuk beras Membramo diperoleh ARIMA $(1,1,0)$ dengan koefisien parameter yaitu: AR(1) $=-0,2922$. Persamaan untuk $\operatorname{ARIMA}(1,1,0)$ untuk beras membramo menjadi:

$$
\begin{gathered}
Z_{t}-Z_{t-1}=\phi_{1}\left(Z_{t-1}-Z_{t-2}\right)+\varepsilon_{t} \\
Z_{t}=(1-0,2922) Z_{t-1}+0,2922 Z_{t-2}+\varepsilon_{t} \\
\quad \hat{Z}_{t}=0,7078 Z_{t-1}+0,2922 Z_{t-2}
\end{gathered}
$$




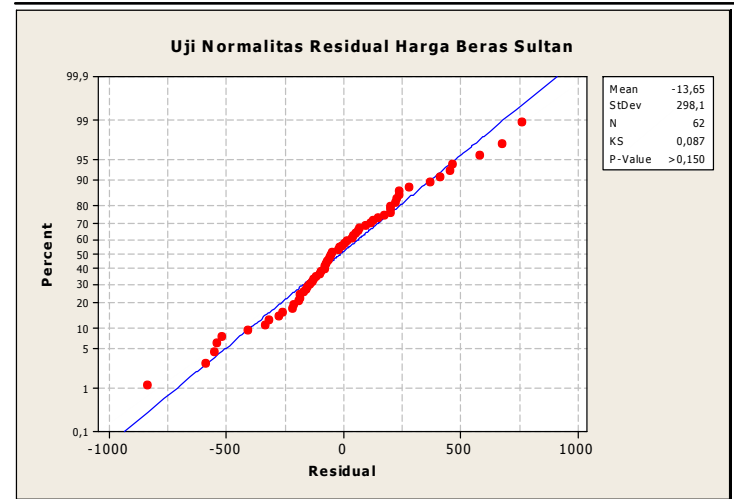

Gambar 3 - Uji Normalitas pada Nilai Residual Harga Bulanan Beras Sultan

Gambar 3 menunjukan bahwa titik-titik merah dalam grafik bergerak mendekati garis normal dengan $p$-value $=0,150$, dimana nilainya lebih besar dari 0,05 .

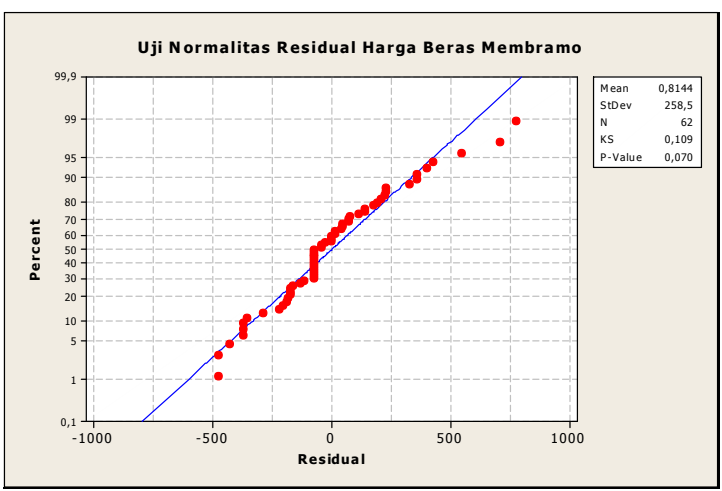

Gambar 4 - Uji Normalitas pada Nilai Residual Harga Bulanan Beras Membramo

Gambar 4 menunjukan bahwa titik-titik merah dalam grafik bergerak mendekati garis normal dengan $p$-value $=0,070$ atau nilainya lebih besar dari 0,05.

Prediksi harga bulanan beras sultan dan beras membramo periode Jan-2007 sampai dengan Mar-2012 diberikan pada Gambar 5 dan Gambar 6.

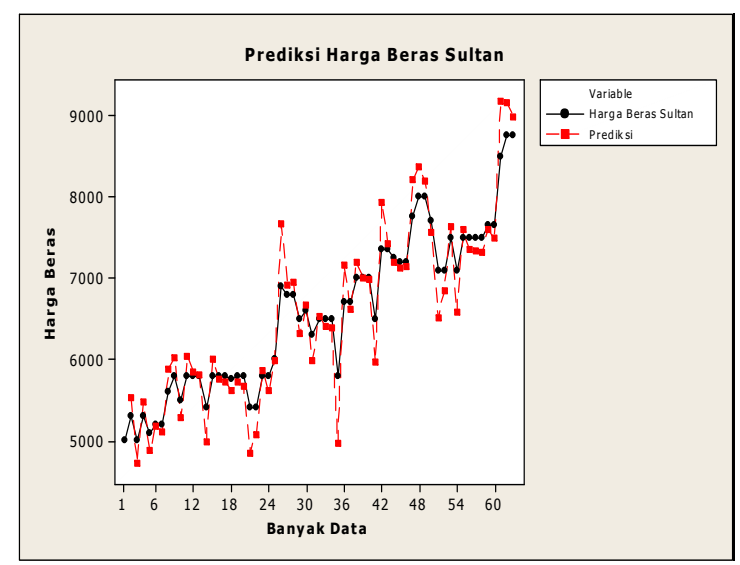

Gambar 5 - Prediksi Harga Bulanan Beras Sultan

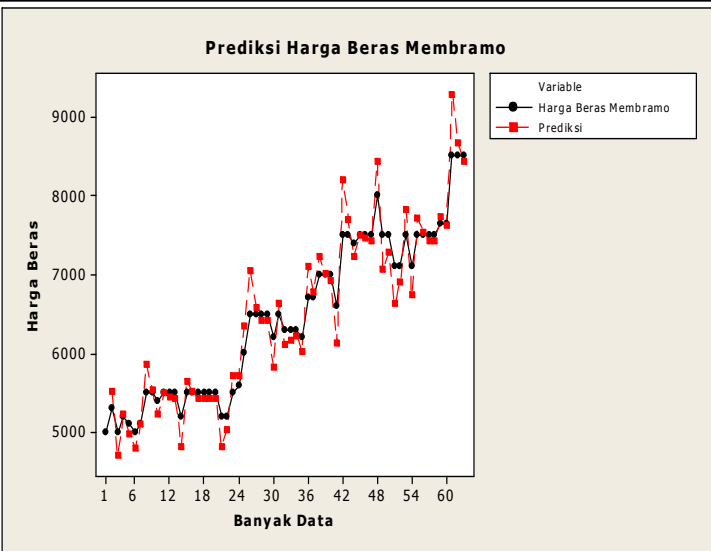

Gambar 6 - Prediksi Harga Bulanan Beras Membramo

Dari Gambar 5 dan Gambar 6 dapat diketahui bahwa hasil perbandingan antara data harga beras yang sebenarnya dengan data harga beras hasil prediksi tidak berbeda jauh.

Prediksi 3 bulan ke depan harga bulanan beras sultan dan beras membramo pada Apr-2012 sampai dengan Jun-2012 diberikan pada Tabel 1 dan Tabel 2.

Tabel 1 - Prediksi Harga Bulanan Beras Sultan pada April 2012 sampai dengan Juni 2012

\begin{tabular}{|c|c|c|}
\hline N0 & Bulan/Tahun & Prediksi \\
\hline 1 & Apr-12 & $8.287,30$ \\
\hline 2 & Mei-12 & $8.338,61$ \\
\hline 3 & Jun-12 & $8.389,92$ \\
\hline
\end{tabular}

Tabel 2 - Prediksi Harga Bulanan Beras Membramo pada April 2012 sampai dengan Juni 2012

\begin{tabular}{|l|l|l|}
\hline N0 & Bulan/Tahun & Prediksi \\
\hline 1 & Apr-12 & 8482,10 \\
\hline 2 & Mei-12 & 8537,80 \\
\hline 3 & Jun-12 & 8593,60 \\
\hline
\end{tabular}

\section{Kesimpulan}

Hasil analisis time series menunjukkan bahwa model yang cocok untuk harga bulanan beras sultan adalah model $\operatorname{ARIMA}(1,1,1)$. Prediksi harga beras pada April 2012 sampai dengan Juni 2012 berkisar antara Rp.8.287 sampai Rp.8.389. Demikian juga, model yang cocok untuk harga bulanan beras Membramo adalah model $\operatorname{ARIMA}(1,1,0)$. Prediksi harga beras pada April 2012 sampai dengan Juni 2012 berkisar antara Rp. 8.482 sampai Rp. 8.593.

\section{Daftar Pustaka}

Box, G.E.P., and Jenkins, G.M. Time Series Analysis : Forecasting and Control. Rev Edition. Holden-Day Inc. San Fransisco, 1967. 
Irawan, N dan Astuti, P, S. Mengolah Data Statistik dengan Mudah Menggunakan Minitab 14. Penerbit Andi. Yogyakarta, 2006.

Mulyana. Buku Ajar Analisis Deret Waktu. Universitas Padjajaran FMIPA Jurusan Statistika. Bandung, 2004.
Nainggolan, N. Model Time Series Heteroskedastik. UNPAD Press. Bandung, 2009.

Sumakul, G.C. Aplikasi Model Arima (Autoregressive Integrated Moving Average) dalam Memprediksi Harga Saham PT.Telkom, Tbk [Skripsi]. FMIPA UNSRAT. Manado, 2011. 